\title{
EL LUGAR DEL INTELECTO AGENTE EN EL PENSAMIENTO DE AVEMPACE
}

\author{
Joaquín Lomba \\ Universidad de Zaragoza
}

\section{RESUMEN}

El objetivo de este artículo es exponer el papel sumamente original del Intelecto Agente en la filosofía de In Bâyyya (Avempace) y los pasos y niveles de conocimiento que nos llevan a lograr la «unión mística» con él (que es el último fin del hombre): el intelecto potencial o material, el intelecto en acto y, finalmente, el Intelecto Agente en el cual las esencias son contempladas sin sustrato material e individual, como puros inteligibles, y en el que el sujeto cognoscente se indentifica con el objeto conocido. Este último estadio y perfección humana es un don que Dios da al hombre después del esfuerzo natural y voluntario que este pone. En esta concepción hay un tránsito original del nivel gnoseológico al existencial y metafísico. Por lo demás, Avempace sigue a Platón, Aristóteles, neoplatonismo, Alejandro de Afrodisa, Proclo, al-Fārāăi y la Enciclopedia Rasā'il ijwān al-safä' y otros.

Palabras clave: Intelecto en potencia, Intelecto en acto, Intelecto Adquirido, Intelecto Agente, Unión mística. Salto gnoseológico-metafísico.

\begin{abstract}
The purpose of this article is to expound the very original role of the Agent Intellect in the Ibn Bāŷỳa's (Avempace) philosophy and the steps and levels of knowledge to achieve the "mystical union» with it (the final goal of man): the potential or material intellect, the intellect in fact, the acquired intellect and, finally, the Agent Intellect in which the essences are contemplated without material and individual substratum, as pure intelligibles, and the cognoscent subject and the object are identical. This ultimate stage and perfection is a gift that God gives to man, after his natural effort. In this conception there is an original transit from the gnoseological level to the existential and metaphysical one. For the rest, Avempace follows Plato, Aristotle, the Encyclopaedia Rasă'il ijwān al-safáa' and others.
\end{abstract}

Key word: Potential Intellect, Intellect in fact, Acquired intellect, Agent Intellect, gnoseologic-matphysical transit

Uno de los temas centrales del pensamiento de Ibn Bāŷŷa, Avempace (Zaragoza. h. 1087Fez, 1138), es el del Intelecto Agente el cual aparece con insistencia en sus obras más importantes siendo abordado en ellas desde distintos puntos de vista. Por otro lado, este problema parece que ofrece un interés muy especial en la falsafa árabe, como muestran los trabajos que en este mismo volumen aparecen de Cruz Hernández, Ramón Guerrero y Josep Puig, sin contar con el impacto en el mundo judio, tal como lo muestra Juan Fernando Ortega. Avempace, en este conjunto, ocupa un lugar especial entre Avicena, al-Fārābi, Averroes y el resto del pensamiento árabe, a la vez que expresa elementos platónicos, neoplatónicos y aristotélicos, como veremos. La postura de Avempace atraerá la atención de Averroes y Tomás de Aquino por su peculiar interpretación, tal como tendremos también ocasión de ver. 
Las obras en que trata de este asunto de una manera más especial son las siguientes: $E l$ régimen del solitario ${ }^{1}$, Risālat al-wad $\bar{a}^{c}$, Carta del adiós ${ }^{2}$, Kitāb $\hat{\jmath}$-l-nafs, Libro sobre el alma ${ }^{3}$, Kalām fî-l-gāyat al-insāniyya, Tratado sobre el fin del hombre ${ }^{4}$, Ittișāl al-caal bi-l-insān, Unión del Intelecto con el hombre ${ }^{5}$, Dif ${ }^{c}{ }^{c}$ an Ab̄ Nașr al-Fārābū aw fi-l-sacāda al-ujrawiyya, Defensa de Abū Nașr al-Fārābù o sobre la felicidad de la otra vida, 'Alà al- ${ }^{c}$ aql al-fac ${ }^{c c} \overline{a l}$, Sobre el Intelecto Agente ${ }^{6}$ entre otros varios tratados menores recogidos por ${ }^{\mathrm{c}} \mathrm{Alaw} \overline{\mathbf{1}}{ }^{7}$.

$\mathrm{Y}$ los puntos de vista desde los que Avempace considera al Intelecto Agente son, entre otros, el gnoseológico, el sociológico-político, el metafísico y el religioso, algunos de los cuales tendré en consideración a lo largo de este breve esbozo sobre el tema que pienso exponer. Todo ello inserto en un marco expresado en un texto que define perfectamente la postura general de Avempace en su filosofía, a saber, el del diseño de un itinerario del hombre que camina desde la materialidad más baja hasta la espiritualidad suma donde se halla el fin supremo de su existencia:

Con la corporeidad, el hombre es un ser existente; por la espiritualidad, es más noble; y por la intelectualidad es un ser divino y perfecto. Así pues, el que tiene sabiduría, es necesariamente un ser perfecto y divino ${ }^{8}$.

En orden a lograr este fin supremo y sublime, Avempace establece una serie de clasificaciones de los hombres las cuales vienen a coincidir todas en el mismo objetivo dicho: en el de que, partiendo del mundo material, sensible, espacio-temporal, compuesto de individuos concretos, lleguemos al desprendimiento absoluto de todo ésto para lograr una espiritualidad en cuyo centro, veremos, está el Intelecto Agente protagonista fundamental de la aparición de la sabiduría humana.

Ante todo, y ello es importante, para comprender no solo el papel del Intelecto Agente en Avempace sino múltiples aspectos de su pensamiento, hay que subrayar la tendencia que éste tiene a reducir lo puramente gnoseológico a existencial, ya se trate de una existencia del orden puramente metafísico o sociológico, político o religioso. Buen ejemplo de ello es la conocida clasificación de los hombres en el ámbito social y humano que establece en el Régimen del solitario, donde, a partir de las formas/almas que constituyen a los seres y de las que, concreta-

1 «El régimen del solitario», Introd. Trad. y notas de J. Lomba, Ed. Trotta, Madrid, 1997

2 Asín Palacios, "Carta del adiós", en Al-Andalus, VIII (1943), pp. 1-87. Actualmente estoy terminando la traducción de esta obra, actualizándola y añadiendo unas páginas que Asín no incluyó, tituladas Qawl yatlü risālat al-wadăc, Lo que sigue a la carta del adiós. En adelante, ya que todavía no está publicada mi traducción, me referiré a la paginación de Asín, pero transcribiendo mi versión.

3 Kitäb al-nafs l-Ibn Bāŷŷa, Edición crítica bajo la dirección de Alzoade y textos establecidos, presentación y estudio de Aouad, M., El Amrani, A., Alozade, M., Alami, A., Moussaid, M., Biard, J., Rachak, J., Rechireke, M., Hassnaoui, A., Centre des Etudes In Rushd; Fez, 1999. Actualmente estoy ultimando la traducción al español de esta obra, con introducción y notas. En adelante citaré esta obra con el nombre Sobre el alma, indicando los folios del manuscrito de Berlín que es el más completo y el que han utilizado los autores antes citados, junto con el de Oxford. Mi traducción también la haré sobre esta edición árabe de ambos manuscritos.

4 "Ibn Bāŷŷa (Avempace)"Sobre el fin del hombre", Introd., Trad. y notas de J. Lomba, en Homenaje a Maria Jesús Rubiera.Mata. Sarq al-Andalus, n. 10-11 (1993-1994), pp. 467-482 En adelante citaré esta obra con el título de Sobre el fin del hombre.

5 "Tratado del Entendimiento Agente de Avempace" Anales del Seminario de Filosofía, Universidad Complutense, Madrid, 1996, pp. 265-274; "«Tratado de la unión del Intelecto con el hombre» de Avempace", en Homenaje a la Profesora Gisbert, Anaquel de estudios árabes, vol. 11, Madrid, 2000, pp. 369-39. En adelante citaré esta obra con el título de Tratado de la unión.

6 «Sobre la felicidad política y la felicidad de la otra [vida] o defensa de Abū Naṣr [al-Fārābī" de Avempace», Introd., Trad. y notas de J. Lomba, Revista del Instituto Egipcio de Estudios Islamicos en Madrid, XXVII (1955), pp. 23-39. En adelante citaré esta obra con el título de Sobre la felicidad en la otra vida.

7 'Alawi, J.D. Rasā'il falsafiyya li-bn Bāŷŷa, Casablanca-Beirut, 1987.

8 Avempace, El Régimen, op. cit., p. 100. 
mente, afectan al hombre referidas en este último caso a sus órganos de conocimiento, establece los tipos humanos y las clases sociales que existen en la vida política, lo cual aprovecha Avempace con profusión para hacer una severa crítica a las sociedades y políticas de su tiempo ${ }^{9}$. Y precisamente esta clasificación nos lleva de la mano a la consideración del Intelecto Agente que me ocupa aquí. Recordemos esta clasificación de manera resumida ${ }^{10}$ :

1. Formas del nivel corporal:

1.1. La forma de la materia tangible y visible espacio-temporal de las cosas

1.2. La forma $o$ alma vegetativa de las plantas.

1.3. La forma o alma animal, provista de los sentidos externos (vista, oído, gusto, olfato y tacto) propia de los animales y del hombre. En el caso de este último, es la forma más baja y material de toda su constitución.

2. Formas del nivel espiritual:

2.1. Las formas de los sentidos internos (sentido común, imaginación y memoria). Estas formas son propias también de animales y de hombres, aunque en este último caso suponen una elevación primera sobre el orden meramente material

2.2. La forma de la razón, la cual solamente la posee el ser humano.

3. Forma del Intelecto que supone una superación del anterior, dado que alcanza ya la plena espiritualidad. Y, dentro de esta forma del Intelecto:

3.1. La forma que es el Intelecto Pasivo ( ${ }^{c} a q l$ munfaf $\left.{ }^{c} i l\right)$ o en potencia ('aql bi-quwwa) individual de cada persona

3.2. La forma que es el Intelecto Adquirido (caql al-mustafad) individual de cada individuo.

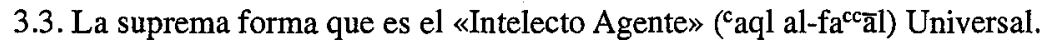

En esta clasificación hay que advertir tres cosas. Primera, a modo de complemento de la misma, en cada uno de los niveles incluye a los distintos tipos de hombres que se encuentran en la sociedad de acuerdo con el uso que haga de las correspondientes facultades y formas. Así, en los apartados 1.3 y 2.1 incluye al vulgo y a ciertas personas y clases sociales nobles y aristócratas, gobernantes o no, de su tiempo que se limitaban a lo más ínfimo de las capacidades humanas. Sin embargo, en el nivel 2.2., la situación cambia, pues aquí se encuentran los hombres de ciencia e intelectuales ocupados en menesteres superiores, más alejados de la pura materia y de la vida sensorial.

Segunda, en orden a la inteligibilidad más teorética de las formas, hay que subrayar la ambivalencia, consciente por lo demás, con que se maneja alternando e identificando el sentido de «forma» referido al alma propiamente tal, con el órgano perceptor y a las formas cognoscitivas que éste adquiere mediante el ejercicio ${ }^{11}$.

Tercera: en este camino ascendente hacia el espíritu, es preciso tener en cuenta la noción que de éste tiene. Identifica alma y espíritu pero reservando, al final, este último término, en su más estricto sentido, a unos seres muy concretos, separados por completo de la materia:

En la lengua de los árabes, «espíritu» se llama a lo mismo que se dice «alma» ${ }^{12}$. Por eso encontramos que los médicos dicen que los espíritus son tres: el espíritu natural, el espíritu sensitivo y el espíritu motor. Por [espíritu] natural entienden al [espíritu] nutritivo,

9 Es precisamente esta crítica negativa que hace de su entorno social, la que lleva a Avempace a concebir la idea del solitario o mutawahhid, que, viviendo físicamente en la sociedad, se aísla de ella internamente para buscar su propia vocación y fin supremo que veremos más adelante centra en el Intelecto Agente. Esta figura del solitario la expone en su libro arriba citado El régimen del solitario y será recogida por In Tufayl novelándola en su libro $E l$ filósofo autodidacto, Trad. A. González Palencia, E. Tornero, Trotta, Madrid, 1995.

10 Avempace, El Régimen; op. cit., pp. 71-80.

11 Una exposición de su concepto de alma y espíritu puede hallarse en El régimen del solitario, op. cit., pp.111-112.

12 Para «espíritu» emplea el término rūḥ, y para «alma», nafs, como es habitual. 
pues, dentro de su arte [médica], llaman «naturaleza» al alma nutritiva. Y sé utiliza [el término de «espíritu»] para el «alma,» no en cuanto que es alma, sino en cuanto que es alma motriz. Así pues, «alma» y «espíritu» son dos cosas [distintas] en cuanto a la elocución, pero una sola en cuanto al objeto. Lo «espiritual» está relacionado con el «espíritu» cuando indica el segundo sentido y aluden [los filósofos con este término de «espiritual»] a las substancias inmóviles <separadas $>^{13}$ que mueven a las demás. Y estas tales necesariamente no son cuerpos, sino formas de los cuerpos, ya que todo cuerpo está en movimiento ${ }^{14}$.

Concluyendo a renglón seguido algo que afecta directamente a la clasificación dicha y al tema que me ocupa:

Por eso opinan $\left[{ }^{15}\right.$ los filósofos] que las substancias más dignas de ser llamadas así son el Intelecto Agente y las substancias que mueven a los cuerpos celestes ${ }^{16}$

Textos que se entenderán mejor con aquella afirmación de el mismo El régimen del solitario, donde dice:

La substancia, cuanto más lejos está de la corporeidad, más digna es de este nombre [de «espiritual» $]^{17}$..

Cuarta, como complemento a esta clasificación de las formas, quiero reproducir un texto que, paralelo a los anteriores y perteneciente al mismo libro de El régimen del solitario, que nos sitúa de nuevo y de una manera más directa con el tema que me ocupa:

Las formas espirituales son de varias clases: primera, las formas de los cuerpos celestes; segunda, el Intelecto Agente y el intelecto adquirido; tercera, los inteligibles materiales 18; cuarta, los contenidos ${ }^{19}$ que se encuentran en las potencias del alma, cuales son los que se hallan en el sentido común, en la facultad imaginativa y en la facultad rememorativa [o memoria]. La primera clase no es material en absoluto. La tercera ${ }^{20}$, tiene relación con la materia: se les llama [a estas formas] materiales porque son inteligibles materiales pero no son espirituales en su esencia ya que su ser reside en la materia. $<{ }^{21}$ Son en cierta manera formas [espirituales] que quedan en la facultad racional (del alma), cuando la relación particular que había entre ella y la cosa individual ha cesado de existir; pues, en tanto que esta relación particular existe, ella [la facultad racional] está siempre afectada por una cierta corporalidad que hace que la relación sea corporal; pero cuando la corporalidad cesa y la facultad deviene en puramente espiritual, no conserva más que

13 «Separadas» lo añade Munk (Mélanges de Philosophie juive et arabe, Paris, Vrin, 1955, p. 394), pues, como señala, Avempace quiere hablar de las Inteligencias de las esferas celestes, llamadas «Inteligencias» 0 «Intelectos Separados». En mis traducciones de los textos árabes, lo encerrado entre corchetes son añadidos de otros manuscritos o de las versiones de Munk.

14. Avempace, El régimen, op. cit. p. 111.

15 En adelante, lo puesto en mis traducciones del árabe entre estos corchetes [] son añadidos que hago para mejor intelección del texto literal original, salo cuando pongo este signo [...] que, como es costumbre hacer, sirve para significar que se saltan algunos párrafos de un texto.

16 Ibidem.

17 Avempace, El Régimen, op. cit., p. 112.

18 Es decir, las especies intelectuales obtenidas por abstracción de los seres materiales mediante el intelecto.

19 Ma`nà (pl. ma $\left.{ }^{\complement} \bar{a} n \bar{r}\right)$ tiene muchos sentidos que varían según el contexto: «significado», «sentido», «concepto», «idea», «pensamiento», «expresión». Aquí, como se trata de los objetos contenidos en los sentidos internos, he preferido dar la versión más amplia de «contenidos», incluyendo el de «intención» y el latino de «species», para no comprometer el de «idea» o «concepto» reservado más bien para la razón e intelecto.

20 En el texto hebreo manejado por Munk; la tercera clase viene a continuación de la segunda. En el texto árabe está antes.

21 Lo puesto entre los signos $<>$ lo añade Munk, sacándolo de la versión hebrea que él maneja. 
la relación universal, es decir, la relación a todos los individuos>. Las [formas de la] segunda clase, bajo este punto de vista, no son materiales en absoluto, porque no fueron materiales necesariamente en momento alguno; su única relación con la materia es que perfeccionan a los inteligibles materiales, y ésto es lo que hace el intelecto adquirido, o los producen, que es lo que hace el Intelecto Agente. Por lo que respecta a la cuarta clase, se trata de un intermedio entre los inteligibles materiales y las formas espirituales ${ }^{22}$.

De este modo, en cuanto respecta al hombre y al desarrollo de sus diversas formas (uniendo los textos citados) empieza éste a utilizar sus capacidades mentales superiores, encarnadas en primer lugar en la razón o nutq (equivalente de modo puntual al $\lambda$ ó $\gamma \circ \varsigma$ griego), encargado de abstraer de lo individual y material los primeros conceptos universales que ya entran en el ámbito espiritual de pleno derecho por haberse empezado a desprender de lo múltiple y cambiante de los individuos materiales mediante la abstracción de conceptos o formas universales. Socialmente abarca, como he dicho antes, a los hombres dedicados a la ciencia, sea ésta del tipo que sea. Así define esta potencia racional en su tratado Sobre el alma:

La potencia racional es aquélla por la que el hombre percibe las cosas que son semejantes [entre sí], de acuerdo con lo que se le presenta a su alma. [Esta potencia] es, en suma, o información, o pregunta o mandato. Pregunta es pedir información, información es enseñanza y preguntar es aprender. Esta potencia es aquélla por la que el hombre conoce o aprende. Estas tres partes únicamente existen cuando el hombre se halla en estado natural. El hablar razonando con palabras notifica [a los demás], de modo convencional, aquellas ideas que se le ocurren al alma del que razona. Hablar-razonando, en la lengua de los árabes, significa ante todo pronunciar palabras que significan ideas. Luego se usa [en el sentido de] pronunciar palabras que no significan nada ${ }^{23}$.

Es el nivel de la ciencia racional. Sin embargo, a pesar de estar en la cima de las capacidades naturales del hombre, no es el máximo grado de espiritualidad que puede alcanzar pues está sometida de algún modo la razón a la multiplicidad y variabilidad, dada la conexión que todavía mantienen sus conceptos universales con los individuos concretos de los que fueron extraídos y a los que se refieren en su significado. Son muchos los lugares en que explica estas características de la razón científica. Baste el siguiente sacado del Tratado de la unión del Intelecto con el hombre:

los teóricos que especulan sobre la naturaleza, consideran primeramente los inteligibles y en segundo término los objetos, y éstos, en razón de los inteligibles por analogía [a los objetos correspondientes]; por eso piensan ante todo en el inteligible, a la vez que la forma material que va unida al inteligible. Esta es la razón por la que todas las proposiciones utilizadas en las ciencias contienen sujetos y predicados singulares y concretos; siendo [a la vez] proposiciones universales ${ }^{24}$.

Esta operación racional y científica está, por otra parte, dentro de las capacidades naturales humanas, como dice él mismo en la Carta del adiós, lo cual es importante subrayarlo para lo que luego diga de la relación divina con el Intelecto Agente.

Sin embargo, en la clasificación de las formas que he dado más arriba, los niveles comprendidos en el apartado 3 y que suponen la máxima espiritualidad y desprendimiento de la materia, son los correspondientes el intelecto o ${ }^{c} a q l$, correspondiente al voū̧» griego. Ellos serán el objeto de mi atención en adelante.

22 Avempace: El régimen, op. cit., p. 112.

23 Sobre el alma, Capínulo XI (fol. 164 b). Es de notar, para mejor entender el texto, que en árabe nataqa significa hablar, como en griego $\lambda \in \gamma \in \iota \nu$, y nuṭ. Expresión hablada, palabra y razón, lo mismo que lovgo» en griego.

24 Avempace, Tratado de la Unión, op. cit. p. 384. 
Por los trabajos que figuran en este número de la revista queda clara la historia del tema del Intelecto Agente en Aristóteles y en la tradición greco-árabe. Por esa razón omito tal recuento histórico, centrándome en nuestro autor In Bāŷŷa, Avempace.

Según éste hay que distinguir entre intelecto en potencia o pasivo ('aql munfacil), intelecto en acto ( ${ }^{c} a q l$ bi-ficl), intelecto en hábito o adquirido ( ${ }^{c} a q l$ mustafād) e Intelecto Agente ('caql $\left.\mathrm{fa}^{\mathrm{cc}} \overline{\mathrm{a}} \mathrm{l}\right)$. El primero de todos es individual y de él habla en el texto de la clasificación de las formas arriba resumido y en el apéndice a El régimen del solitario que Munk trae como un añadido de Moisés de Narbona, traductor al hebreo del Régimen del Solitario, y que Asín Palacios califica de apócrifo ${ }^{25}$. Allí, dice, entre otras cosas:

y con ella [con la potencia racional] percibe [el hombre] su propia esencia como percibe las otras esencias, con esta diferencia: que él percibe su propia esencia en toda su realidad, mientras que no percibe las otras esencias más en cuanto que son distintas de la suya y en cuanto que las abstrae y las convierte en cosas inteligibles ${ }^{26}$

Ahora bien, esa potencia racional, como he dicho, percibe las esencias de las cosas materiales distintas a ella misma, mediante la abstracción, en cuyo proceso, la imaginación (acompañada del sentido común) desempeña un papel fundamental, siguiendo la psicología aristotélica. Las imágenes o fantasmas emanadas de esta imaginación, iluminados por el Intelecto Agente, harán que el intelecto en potencia o con capacidad de conocer los conceptos universales, pase a intelecto en acto o percepción real y actual de esos conceptos. La iluminación del Intelecto Agente, por tanto, sobre estos fantasmas e imágenes es fundamental para la conceptualización de las primeras esencias universales.

Veo que tú, dada tu perfección, te das cuenta [de que tienes] esta visión que percibe [los inteligibles] en los fantasmas [de la imaginación] y que te resulta evidente que hay en el alma algo que se parece a la claridad procedente del sol o de otra cosa [similar], con la cual el alma capta [con igual evidencia con la que] percibe la visión [de los ojos] gracias a la claridad del sol. Y que ves al alma esculpir con esta [forma de] visión [los inteligibles] en la imaginación de manera parecida a como lo hace quien ve con la visión de los ojos *27 Y a esto se llama reflexión, la cual es preciso [hacer] con la vista [intelectual]. Y, puesto que el hombre se perfecciona mediante la consecución de inteligibles, como no [puede] abarcar [todo] lo que se puede alcanzar en la facultad imaginativa y lo que se deriva necesariamente del conocimiento de aquellos inteligibles, siendo así que su acto está en la esencia [del intelecto] y no en la potencia imaginativa, entonces tiene lugar su conceptualización y su acción dentro de la esencia [del intelecto], en el seno de unos inteligibles universales, no en unos fantasmas de individuos particulares que tengan lugar gracias a unos individuos; de este modo ya no se vuelve a los fantasmas de los individuos que están en la imaginación, como [es a] la imagen de Zayd, de ${ }^{c}$ Umar y de este caballo

25 Sin embargo, en mi traducción al español de El régimen del solitario, incluí este fragmento tal como lo trae Munk (Mélanges..., op. cit., pp. 405-409) pues, en primer lugar, seguramente Moisés de Narbona, más cercano que nosotros en el tiempo a Avempace y, por tanto, mejor conocedor de su pensamiento, halló en este pasaje un complemento valioso al contenido incompleto de El régimen del Solitario; y, en segundo término, creí que es importante reproducir El régimen del solitario tal como se conoció en la Edad Media, a través de la versión hebrea, aunque no fuera tal vez realmente el texto que salió de las manos de Avempace. En cualquier caso, el contenido de este apéndice, al menos en el punto que ahora me ocupa, encaja perfectamente en el cuadro general del pensamiento de Avempace.

26 Avempace $E l$ régimen, op. cit. pp. 176 y ss.

27 Lo encerrado entre asteriscos es sumamente difícil de entender, dadas las lagunas que hay en el texto y lo dudoso de la interpretación de los manuscritos empleados. La versión e interpretacipón que le doy es, por tanto, insegura, por las razones dadas. 
[.....]. Lo imaginado es aquel individuo en sí mismo y no para otras cosas $\mathrm{Y}$ el Intelecto, con respecto a este [individuo] lo mira con la visión del alma ${ }^{* 28}$

Lo cual queda confirmado con todo lo que dice en su libro Sobre el alma, especialmente en el capítulo décimo ${ }^{29}$ dedicado a la imaginación y en el undécimo ${ }^{30}$ a la facultad racional, sobre todo, en los folios recientemente hallados del manuscrito de Berlín, editados hace poco por M. Alozade, en la obra que he indicado en la nota 3.

Todo lo dicho supone una serie de distinciones de niveles de conocimiento superior de sumo interés para la correcta interpretación del Intelecto Agente. En su Libro sobre el alma dice:

La abstracción [tiene varios] grados. Cada uno de los grados son llamados «alma» y "potencias del alma» siendo éstas de varios niveles: la sensación, luego la imaginación y después la razón que es la última de todas ${ }^{31}$

En cuanto a El régimen del solitario, ya hemos visto más arriba sobradamente la gradación de intelecciones que establece Avempace. Pero tal vez donde es más claro es en el Tratado de la unión del intelecto con el hombre, donde dice:

Está claro, por lo que hemos dicho aquí, que hay tres grados. El primero es el nivel natural. Los que están en él, únicamente tienen el inteligible que está unido a las formas materiales, no sabiendo nada de [este inteligible] más que mediante [esas formas materiales], a propósito de ellas, desde ellas y para ellas. Aquí entran todas las artes prácticas El segundo es el conocimiento intuitivo especulativo que está en la cima de lo natural. El vulgo considera los primeros objetos y los inteligibles en segundo lugar y esto [último] en razón de sus objetos, mientras que los teóricos que especulan sobre la naturaleza, consideran primeramente los inteligibles y en segundo término los objetos, y éstos, en razón de los inteligibles por analogía [a los objetos correspondientes]; por eso piensan ante todo en el inteligible, a la vez que la forma material que va unida al inteligible. [...]. En este [segundo] nivel teórico, el sujeto ve el inteligible pero a través de intermediarios, como se ve el sol en el agua, puesto que lo reflejado en el agua es una imagen del sol, no el sol mismo. La gente vulgar ve imágenes de imágenes [del inteligible] como cuando el sol lanza su imagen sobre el agua y [esta imagen] se refleja en un espejo, en el cual se ve algo que no es el individuo [real] ${ }^{32}$. El tercer nivel es el de los hombres felices que ven la cosa en sí misma. ${ }^{33}$.

Es evidente que las alusiones a la luz, al sol y a la visión, son de clara raigambre platónica, cosa que lleva a cabo en otras partes, por ejemplo en El régimen del solitario, con otros fines, como son los políticos, al echar mano del mito de la caverna.

Ahora bien, una vez logradas las esencias universales del segundo nivel, mediante la abstracción inteligible de la materia, mediante la imaginación y el paso del intelecto en potencia a acto, aparece el intelecto en hábito y el Intelecto Agente, como dice en El régimen del solitario en el texto que he citado en la página 36.

Así pues, una vez logrado el paso del intelecto en potencia a acto, cuando éste reflexiona sobre sus propios inteligibles abstractos, pero considerándolos en sí mismos y sin conexión al-

Avempace. Sobre la felicidad en la otra vida, op. cit., p. 38.

Avempace, Sobre el alma, Ms. B. Fol. 172 v y ss.

Avempace, Sobre el alma, Ms. B Fol. $174 \mathrm{r}$.

Avempace, Sobre el alma, Ms. B Fol. $161 \mathrm{~V}$.

32 Un pasaje similar relativo a la visión, el sol y los inteligibles se encuentra en La carta del adiós, op. cit.

33 Avempace, Tratado de la unión, op. cit., p. 384. 
guna con los individuos y la materia de los que los extrajo, aparece el intelecto adquirido que en ocasiones le llama emanado, con lo cual establece una clara conexión con el neoplatonismo a pesar de su encuadre general aristotélico. Antes he hecho alusión al epítome de la versión hebrea añadido a El régimen del solitario. De nuevo acudo a él pues encontraremos abundantes datos sobre el intelecto adquirido:

\begin{abstract}
el fin hacia el cual debe tender el solitario que desea la inmortalidad no está, en modo alguno, en relación con la materia; razón por la cual se dirige al verdadero fin donde incluso desaparece esa relación universal de que hemos hablado. Allí, en efecto, la forma está completamente despojada de corporeidad y no es ya ni un solo instante forma material; pues [el solitario] percibe las formas aisladamente y en sí mismas, sin que hayan sido abstraídas de unas materias. $Y$, en efecto, su verdadera existencia consiste en su existir en sí mismas, aunque sean abstractas. Esa es la concepción inteligible, quiero decir, el intelecto en su existencia real o intelecto en acto; es la existencia del intelecto emanado, el cual, más que cualquier otra cosa, se parece al Intelecto Agente. Esta forma emanada no tiene ninguna relación con la materia, si no es en cierto modo, es decir, como entelequia de los inteligibles materiales; pues es en cierto modo el intelecto en acto el que es el substrato del intelecto adquirido o emanado. En efecto, cuando las formas llegan a ser inteligibles en acto, ellas son el término de los seres de este mundo; y por eso mismo que ellos son inteligibles en acto, se cuentan dentro del número de los seres [...] Ahora bien, si después de haber sido inteligibles en potencia, son pensados por segunda vez, su ser ya no es el anterior sino que está separado de su materia; pues son éstas las formas que ya no están en su materia sino inteligibles en acto. Así pues; cuando el intelecto en acto piensa las cosas inteligibles, las cuales son formas en tanto que son inteligibles en acto, este mismo intelecto que hemos llamado al principio intelecto en acto es, a partir de ahora, intelecto adquirido. [...] El intelecto adquirido [...] es en sí mismo una forma para el intelecto en acto el cual, a su vez, es como un substrato y una materia para el intelecto adquirido; [de otro lado] el intelecto en acto es una forma para la substancia [en la cual reside] y esta substancia es como una materia ${ }^{34}$.
\end{abstract}

De este modo el Intelecto adquirido es la cima a la que llega el hombre con sus propias fuerzas. Se ha logrado la máxima espiritualidad. Allí ya no hay un substrato del cual se puede abstraer una esencia. Se trata por tanto de una esencia que no tiene esencia abstraíble, la cual será una substancia separada, a saber un intelecto que se piẹnsa a sí mismo, pues de lo contrario llegaríamos a un proceso infinito en el cual, de una esencia podríamos abstraer otra superior y así sucesivamente, lo cual es absurdo, tal como resume Averroes el pensamiento de Avempace en su Commentarium magnum de anima ${ }^{35}$ donde, además hace una comparación entre lo que Avempace sostiene en el Tratado de la Unión y en el Sobre el alma. Omito reproducir el largo pasaje de Averrooes pues no aportaría nada especialmente nuevo a cuanto he dicho. $\mathrm{Y}$ el propio Tomás de Aquino dice lo mismo de Avempace a este respecto, haciéndose eco de dicho testimonio de Averroes (ya que seguramente no conocía directamente la obra de Avempace):

Refiere Averroes que un filósofo llamado Avempace opinaba que, según los principios de la verdadera filosofía, podemos llegar al conocimiento de las substancias inmateriales por médio del de las materiales, pues siendo nuestro entendimiento capaz de abstraer de la materia sensible su esencia, si en esta quedase aún algo de materia, podría de nuevo abstraerla, y, siendo posible prolongar este proceso hasta el infinito, debería, por fin, llegar

34 Avempace, Régimen, op. cit. pp. 176 ss.

35 Averrois Cordubensis, Commentarium magnum in Aristotelis de anima libros, Ed. F.T. Crawford, The Mediaeval Academy of America, Massachussets, 1953, pp. 491-492. 
a entender alguna esencia totalmente inmaterial. En eso precisamente consiste la intelección de las substancias inmateriales ${ }^{36}$

Y aquí se encuentra el salto que opera Avempace desde la perspectiva gnoseológica a la ontológica. En efecto, esa esencia que no tiene esencia resulta ser una substancia pensante que se piensa a sí misma, la cual es el Intelecto Agente, tal como hemos visto en los textos anteriores de $E l$ régimen del solitario y de Averroes. Y que es una reproducción del Motor Inmó-

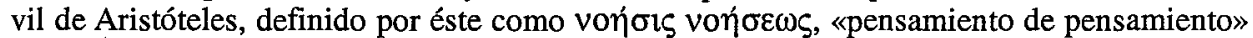
o «pensamiento que se piensa a sí mismo» Así, dice en su Sobre la felicidad política y la felicidad de la otra vida, hablando de este intelecto último, el Intelecto Agente, comparándolo al final con el humano:

Una substancia que es intelecto y que no necesita en su ser de la materia. La substancia más excelsa de [todas] ellas es el intelecto el cual entiende por un inteligido que es su propia substancia. Pues el cognoscente y la ciencia [que son tales] gracias a un [objeto] conocido que es su propia esencia, no necesitando de otra esencia a la cual conozca y entienda, sino a su [propia] ciencia por sí misma, [ese tal] conoce todos los seres que adquieren el ser gracias a la perfección de su propia esencia. Y él los conoce por el conocimiento que tiene de la perfección de su [propia] esencia, pues conoce todo lo que emana de él, según sus grados. Por eso conoce los detalles de las cosas que existen gracias a aquel a quien le fue dado [conocer] aquello mediante el conocimiento de su propia esencia, en la medida en que le fue dado. Y no se le oculta ningún secreto. Y cualquier otro intelecto [distinto a éste] únicamente adquiere aquel [conocimiento] por un inteligido que no es su propia esencia, ya sea uno o más de uno [ese inteligido]. Y el más bajo de [los intelectos] es el intelecto del hombre porque únicamente utiliza el intelecto a base de muchos inteligibles que no son su propia esencia ${ }^{37}$

Hay que notar la obvia rectificación que opera Avempace sobre el Motor Inmóvil aristotélico, a saber: mientras que en este se trataba de una especie de Dios que solo se conocía a sí mismo prescindiendo por completo del mundo, en el caso de Avempace, ocurre que al tratarse del verdadero Dios, se conoce a sí mismo, cierto, pero, en ese mismo acto de autoconocimiento sabe también de lo que $\mathrm{El}$ ha creado y ordenado del mundo.

Con ello hemos llegado a un Intelecto que es uno internamente al pensarse a sí mismo, espiritual en su esencia y separado de la materia y de lo individual y concreto. $Y$ ese Intelecto Agente, además de tener la función de iluminar al intelecto humano para que lanzando su luz sobre los fantasmas e imágenes pueda pasar del intelecto en potencia al intelecto en acto que capta las esencias convirtiéndose luego, por el procedimiento indicado, a intelecto en hábito. Todo ello constituye el fin último del hombre, como dice en el Tratado de la unión del Intelecto con el hombre:

En cuanto àl Intelecto cuyo inteligible es él mismo, no tiene forma espiritual alguna que le sirva de objeto pues lo que se entiende de ese intelecto es lo mismo que se entiende de su inteligible, siendo así uno y no múltiple, ya que carece de la relación que lo ata con la forma que hay en la materia. La contemplación [que procede] de esta manera es la otra vida y [constituye] la única felicidad humana final ${ }^{38}$. Entonces es cuando se contempla

36 Tomás de Aquino, Summa. Theol., I, q. 88, ad 2.

37 Avempace, Sobre la felicidad política y la felicidad de la otra vida, op. cit. p. 32.

38 En esta afirmación, entre otras, se basó la acusación de herejía de Avempace pues parecía que o negaba la vida futura o la situaba ya en la presente. Sin embargo, en la obra ya citada Sobre la felicidad política y la felicidad de la otra vida. Defensa de Abū Nașr al-Fāräbr, afirma repetidas veces que ciertamente existe otra vida, distinta de la presente sensible y que se da después de la muerte. Así, dice allí taxativamente: «Respecto a la sospecha que recae sobre Abū Nașr [al-Fāräbī] en su comentario al libro de la Etica, de [haber dicho] que «no hay perviven- 
este magnífico espectáculo. Y, puesto que la contemplación y comprensión de algo sólo se consigue por el que contempla mediante la idea de algo, despojada de su materia, y como la idea que queremos entender es una idea que carece de idea, resulta que el acto de ese intelecto es su propia substancia, que no puede desaparecer ni perecer, y que [en este intelecto] el motor es el mismo móvil. Y, como dice Alejandro [de Afrodisia] en su libro Sobre las formas espirituales ${ }^{39}$ vuelve sobre sí mismo. Este [intelecto] es uno numéricamente y es el motor primero que actúa por semejanza, de tal modo que quien se asemeja a él resulta ser uno numéricamente aunque múltiple en cuanto a los instrumentos, ya sean éstos espirituales o corpóreos. Ya se explicó ésto en la Carta de la adiós. ${ }^{40}$. Si fuese posible que quien llega a este grado regresase y volviese, si fuese ésto viable, sería este tal un moverse y mover. Pero ésto no es posible. Por eso dicen algunos maestros sufíes ${ }^{41}$ : «Si llegan [los hombres a este estado] no regresarán». Sin embargo, es posible en Aristóteles y en los que siguen su método, un estado parecido al descenso y a la vuelta y otras ideas parecidas que significan estos nombres pertenecientes a actos que se dan en la situación intermedia, y ello, en cuanto que se trata de un estado de ascenso ${ }^{42}$.

Texto que S. Pines y B. Lewin ponen en paralelo con otros dos de Proclo y de Alejando de Afrodisia (los cuales reproduce Altmann ${ }^{43}$ ). Concretamente con las proposiciones 15,16 y 17 del libro de Proclo, Los elementos de Teología ${ }^{44}$ demostrando así el origen neoplatónico claro de esta postura de Avempace.

Por tanto se trata de una unión cuasimística del Intelecto humano con el Intelecto Agente, mediante la contemplación. Contemplación que deviene en un estado ontológico de real y existencial unidad con él. Avempace emplea la palabra ittișāl que deriva del neoplatonismo. Un ejemplo de texto entre otros que se podrían aducir de Plotino:

Puesto que las almas son ellas mismas inteligibles [...] uno debe pensar que la unión [sunavptein], del que entiende [to; noun] con el inteligible [to; katanouvmenon] se logra por diferentes potencias y, más aún, que el inteligente une por virtud de la similaridad e identidad, y se une [sunavptein] con él en virtud de su naturaleza común, cuando no hay obstáculo ${ }^{45}$

Más aún, puestos a señalar más fuentes de Avempace en este punto, se puede decir que además de seguir la línea de Alejando de Afrodisia, al que cita repetidas veces a lo largo de su obra, dentro del pensamiento árabe, en primer lugar, a las $R a \bar{a}^{c} i l$ ijwān al-șaf $\bar{a}^{c}$, Enciclopedia de los Hermanos de la Pureza ${ }^{46}$, para los cuales la cima de la perfección humana estaba en la

cias o [vida] distinta después de la muerte, de que no existe felicidad fuera de la felicidad política, de que no hay más existencia que la sensible y de [afirmar] eso que se dice de que hay otra existencia aparte de la sensible es cuentos de viejas, todo ésto es vano y falsedad [vertida] contra Abu Nașr [al-Fārāb̄]]», Sobre la felicidad política y la felicidad de la otra [vida] o defensa de Abu Nașr [al-Färābl, op. cit., pp. 29-30.

39 Según Asín este libro es desconocido y al parecer no existió. Sin embargo, Alexander Altmann en su trabajo «Ibn Bāŷŷa on man's ultimate felicity», Studies in Religious Philosophy and Misticism, Londres, 1969, pp 73107, dice en la p. 96 que, según S. Pines y B. Lewin, se trata de una versión árabe del libro de Proclo, Los elementos de Teología.

40 Aunque en la Carta de la adiós hace alusión en varios lugares a este tema, sin embargo, parece que el que más se aproxima a lo que dice es en la p. 84, de la versión y edición de Asín.

41 Como subraya Asín Palacios, alude a la doctirna șưfí sobre el retomo del éxtasis a la vida consciente normal. Cfr. Asín, El Islam cristianizado, (reimpresión de la obra original de 1931) Hiperión, Madrid, 1981 pp. 225, 443-444.

42 Avempace, Tratado de la unión, op. cit. p. 383.

43 Altmann, A., Ibn Bāŷya on man's ultimate felicity, op. cit., p. 97.

44 Proclo, Los elementos de Teología (ed. de E.R. Dodds, Oxford, 1933, pp. 16 y ss).

45 Enneada VI, IX, 8. Texto reproducido por Altmann, A., Ibn Bāŷŷa on man's ultimate felicity, op. cit., p. 103.

46 Obra šíi que, escrita en Oriente entró en al-Andalus por Zaragoza, de mano del médico cordobés alKirmānj hacia el año 1060 , obra que influyó poderosamente en el pensamiento musulmán y judío de Zaragoza y de su Reino de Taifas. 
unión mística con Dios. En segundo término a los sufíes, a quienes quiere rebatir y superar, sustituyendo el orden emocional y sensible que éstos centraban en la unión mística, según la interpretación de Avempace ${ }^{47}$ por otro superior que en el caso de nuestro autor podríamos por ello calificar de sufismo intelectual. Y, finalmente se detecta la huella de al-Fārāb̄̄, para el cual el fin último del hombre también es la unión con el Intelecto Agente, pero con alguna diferencia: al-Fārābī se centra en la sola abstracción y en el nivel epistemológico para ascender desde él al Intelecto Agente. Avempace, en cambio, une este proceso de abstracción a una progresiva desmaterialización ontológica y entrada directa en el mundo espiritual, que es el que le interesa, hallando la máxima espiritualidad en la unidad simple del Intelecto Agente consigo mismo y en la unión del hombre con él. Más aún: todos los hombres se unen entre sí ontológicamente cuando llegan a fundirse con el Intelecto Agente. El texto de Avempace es bien claro:

En suma, si este Intelecto es numéricamente uno, todos los individuos que tienen tal In-
telecto, serán [también] numéricamente uno. Es como si tomas una piedra imán y la en-
vuelves de cera; [el imán] moverá a este hierro o a aquel otro. Si luego la recubres con
brea, moverá también al hierro con aquel [mismo movimiento]. Si luego la envuelves con
otros cuerpos, todos ellos serán motores numéricamente uno, como el piloto en la nave.
Igual ocurre aquí [con el Intelecto], sólo que no es posible que, en el caso de los cuer-
pos, uno de ellos sea uno con los demás en el mismo momento, como es posible que sea
en los inteligibles ${ }^{48}$.

Frente a esta afirmación se levantaron numerosas acusaciones de herejía (al dar la impresión de negar la inmortalidad personal del hombre en la otra vida) por parte del mismo islam y del ámbito cristiano de Alberto Magno en sus dos obras, sobre todo Libellus contra eos qui dicunt quod post separationem ex omnibus non remanet nisi intellectus unus et anima una 49 y en Utrum una sola anima intellectualis sit in omnibus corporibus vel multae, ita quod singulae in singulis corporibus. ${ }^{50}$ y de Tomás de Aquino en la Summa contra Gentiles, en el comentario al tratado aristotélico De anima y en el opúsculo De unitate intellectus contra averroistas.

Pero quedan varios puntos por aclarar en el pensamiento de Avempace en torno al tema del Intelecto Agente.

El primero es el planteado por Aristóteles sobre la unidad y separación del Intelecto Agente respecto de los individuos y del mundo Avempace, siguiendo la tradición griega y árabe, lo soluciona afirmando que es separado y único para todos los seres humanos. En ello sigue une vez más a Alejandro de Afrodisia que, con la terminología de Aristóteles, lo califica de ó voós ò $\theta u ́ \rho \alpha \theta \varepsilon v$, Intelecto separado.

El segundo es averiguar si ese Intelecto Agente es el mismo Dios o un intermediario entre el hombre y Dios, en ambos casos, visto desde la perspectiva filosófica. Probablemente se sintió atraído Avempace por la idea de su maestro Alejandro de Afrodisia de identificarlo con Dios. Pero, por otra parte, ello podía chocar con la ortodoxia más pura musulmana y salirse, además, de las directrices de su otro maestro al-Fārābī, para quien el Intelecto Agente era el motor último de la esfera celeste de la luna plasmado simbólicamente, con argumentos persuasivos, en el Angel Gabriel de la religión. Por todo ello, Avempace, fluctúa claramente entre una visión puramente religiosa y divina de dicho Intelecto y una interpretación de pura mediación con la

47 Avempace, El Régimen, op. cit.,p. 58-60.

48 Avempace, Tratado de la unión, , p. 379.

49 Alberto Magno, Libellus contra eos qui dicunt quod post separationem ex omnibus non remanet nisi intellectus unus et anima una, Ed. Jammy, 1651, t. V, p. 232.

50 Alberto Magno, Summa Theologiae, Ed. Jammy, t. XVIII, pars., II, tr. XIII. 
Divinidad, con lo cual, la unión mística con él, resultaría ser un acontecimiento religioso, se viera por donde se le viera. De hecho, dado que el Intelecto Agente, que se piensa a sí mismo y a los inteligibles que se identifican con él, los cuales no tienen ninguna relación con la materia, pone como primer inteligible suyo la idea de Dios. Por tanto, el unirse el hombre a ese Intelecto Agente, equivale, en alguna manera, de forma solapada e indirecta, a unirse con el mismo Dios, $o$, al menos, con su idea:

El régimen político supone una gran ayuda para el ser del intelecto del hombre, principalmente [si se trata de] la ciudad perfecta y del régimen perfecto cuya finalidad última es la existencia del intelecto por medio de muchos inteligibles, el primero de los cuales es Dios, sea honrado y ensalzado, así como sus ángeles, sus libros, sus enviados y todas sus creaturas ${ }^{51}$

Y un poco antes, en el mismo tratado, afirma:

[Este tal] es consciente de su facultad racional para inventar bienes ciudadanos, de acuerdo con su rango, tanto si es un servidor como si es servido o ejerce la política. Y esto no es [la] otra existencia [de la otra vida], de acuerdo con lo que claramente dijeron los antepasados, a pesar de que aún no les había llegado lo que habría de traer la ley divina. Esta no es la perfección [auténticamente] humana — dada la preeminencia que caracteriza [al hombre] basada en la nobleza en el ser que tiene entre los demás animales- [sino que] la que le pertenece especialmente al hombre es [la perfección] del intelecto, con la que logra los inteligibles invisibles mediante los cuales se acerca al Principio [Dios], no necesitando para estar así de la materia, pues no [se trata de] una existencia sensible. Esto [es propio de] la especulación metafísica, mientras que la existencia sensible lo es de la física ${ }^{52}$.

Por otra parte, dice en la Carta del adiós:

Así, el intelecto es el ser más amado por Dios, ensalzado sea. Por tanto, cuando el individuo humano llega a ser ese intelecto, en sí mismo ${ }^{53}$ no existe diferencia alguna entre ambos, bajo ningún aspecto y en ninguna circunstancia y, entonces, llega el hombre a ser la creatura más amada por Dios, estando más cerca de El cuanto más cerca está [de ese intelecto], complaciéndose así Dios en él. Y esto únicamente se consigue con la ciencia, pues la ciencia acerca a Dios y la ignorancia aleja de El. Pero la ciencia más noble de todas es esta que hemos dicho. Y el grado más elevado de la misma es el grado en el cual el hombre llega a concebir su propia esencia hasta el punto de que llega a concebir ese intelecto que dijimos antes. ${ }^{54}$

Pero este tema viene unido al tercero que quisiera plantear, a saber: el de si esa unión con el Intelecto Agente es fruto exclusivo de la natural actividad y esfuerzo humano o si más bien es un don gratuito divino. En el segundo caso, estaríamos en la línea de la visión religiosa y cuasidivina del Intelecto Agente de Avempace. En el primero, situaríamos la unión con el Intelecto Agente dentro del ámbito de las posibilidades puramente naturales y racionales del hombre.

De hecho, In Tufayl le echa en cara que haya procedido de esta segunda manera en su $E l$ filósofo autodidacto:

51 Avempace. Sobre la felicidad en la otra vida, op. cit., p. 34.

52 Avempace. Sobre la felicidad en la otra vida, op. cit., p. 32.

53 Alude, sin duda a lo que dice Aristóteles en la Etica a Nicómaco, 1. 10, 1172 a 6 y 1178 a 6.

54 Avempace. Carta del adiós, op. cit., p. 84-85. 
lo que yo entiendo por percepción de los hombres que investigan la verdad por las solas fuerzas de la razón es aquéllo que ellos perciben de lo metafísico o suprasensible, como lo que percibió Abū Bakr [Ibn Bâŷya, el cual...] prostituyó este deleite ofreciéndoselo al vulgo; lo atribuyó a la facultad imaginativa y prometió describir de una manera clara y precisa cómo debe producirse entonces el estado de los bienaventurados ${ }^{55}$.

Y, Averroes incide en lo mismo en su Gran Comentario al De anima, solo que poniendo en duda la auténtica postura de Avempace, ya que detecta cierta ambigüedad en sus posturas:

Y Avempace parece ser ambiguo en este punto. Pues dijo en la llamada Carta del Adiós que la posibilidad es de dos modos: natural y divina; es decir, que la intelección de este Intelecto [Agente] es una posibilidad divina, no natural. En cambio en la carta sobre la Unión, dijo: «Y cundo el filosofo asciende con otra ascensión considerando al intelecto en cuanto intelecto, entonces entiende la substancia abstracta». Y es manifiesto por ello que entender aquel Intelecto [Agente], es parte de las ciencias especulativas, a saber de la Ciencia Natural ${ }^{56}$.

Y Alberto Magno en su De anima se hace eco de lo mismo con estas palabras:

Avempace, en cambio [...] añadió que el hombre, según el intelecto, tiene dos virtudes: una humana que tiene en cuanto que se forma con fantasmas, otra divina que tiene en cuanto que es vestigio de lqas inteligencias separadas. Por la humana entiende los conceptos con la materia; por la divina, en cambio, las cosas separadas ${ }^{57}$

En efecto, Avempace, en la Carta del adiós dice lo siguiente:

Nuestros santos antepasados dijeron que la posibilidad es de dos clases: la natural y la divina. La natural es la que se consigue por la ciencia, pudiendo el hombre conocerla por sí mismo ${ }^{58}$.

Sin embargo, hay que notar, en primer lugar, que, a continuación de este texto, sigue en una línea de indudable sabor religioso en la que cabe pensar que el conocimiento humano natural se ve completado necesariamente por el otro, por el divino, como de hecho ha sucedido en el Islam:

La [posibilidad de adquirir la ciencia de manera] divina es la que se logra únicamente con la ayuda de Dios. Por eso Dios envió a sus emisarios instituyó a sus profetas, para que nos informasen a todos los hombres de las posibilidades divinas, porque quiso, ensalzado sea su nombre, completar el más excelso de sus dones [concedido a] los hombres, a saber, la ciencia. En efecto, todo lo que viene en las leyes [religiosas] es una incitación a la ciencia y en nuestra ley divina hay cosas que indican esto. Por ejemplo, el dicho [de Dios], honrado sea su nombre, en el libro revelado: «Los arraigados en la ciencia dicen: creemos en ello, todo procede de nuestro Señor» ${ }^{59}$ Lo cual indica las posibilidades divinas. Y su dicho excelso: "Solo tienen miedo de Dios aquellos de sus siervos que saben ${ }^{60}$. En efecto, quien conoce a Dios con auténtica ciencia, sabe que la mayor desgracia es la ira de Dios y el estar alejado de él, mientras que la mayor felicidad es el poder

Ibn Tufayl, El filosofo autodidacto, op. cit., pp. 34-35.

Averrois Cordubensis, Commentarium magnum in Aristotelis de anima libros, op. cit., p. 494.

Alberto Magno, Opera omnia, III, 1. III, cap. VIII.

Avempace, Carta del adiós, op. cit.,. p. 84.

Corán, 3, 7.

60 Corán, $35,28$. 
contentarle y estar cerca de El; y el hombre no se acerca a El, si no es por el conocimiento intuitivo de su esencia. Por eso se cita [este texto] suyo [del Profeta], Dios lo bendiga y lo salve: «Dios creó el intelecto y le dijo: Avanza. Y avanzó. Luego le dijo: Retrocede. Y retrocedió. Y luego añadió: Por mi poder y majestad, juro que no creé ninguna creatura más amable para mí que tú» ${ }^{61}$. Así, el intelecto es el ser más amado por Dios, ensalzado sea. Por tanto, cuando el individuo humano llega a ser ese intelecto, en sí mismo ${ }^{62}$ no existe diferencia alguna entre ambos, bajo ningún aspecto y en ninguna circunstancia y, entonces, llega el hombre a ser la creatura más amada por Dios, estando más cerca de El cuanto más cerca está [de ese intelecto], complaciéndose así Dios en él. Y esto únicamente se consigue con la ciencia, pues la ciencia acerca a Dios y la ignorancia aleja de El. Pero la ciencia más noble de todas es esta que hemos dicho. Y el grado más elevado de la misma es el grado en el cual el hombre llega a concebir su propia esencia hasta el punto de que llega a concebir ese intelecto que dijimos antes ${ }^{63}$.

En segundo lugar, que el testimonio del Tratado de la unión es más claro y preciso que el anterior, puesto que, al parecer, este escrito lo compuso con posterioridad al primero, con lo cual manifiesta de una forma más definitiva su pensamiento, aparte de estar en la línea religiosa del anterior. Dice éste lo siguiente en dicho Tratado de la unión:

Es claro que el Intelecto que es uno, es un premio y don de Dios [que concede] a sus siervos que le tienen satisfecho. Por eso, no es [el Intelecto] el premiado o castigado, sino que la recompensa y el don [recaen] sobre el conjunto de las potencias del alma, aunque el premio y el castigo correspondan sólo al alma apetitiva, que es la que hierra y peca. El que obedece a Dios y hace lo que le complace, El le premiará con este Intelecto y pondrá ante él una luz para que le guíe. Y quien desobedezca a Dios y realice los actos que no le complacen, será privado de [este Intelecto] y permanecerá en medio de las tinieblas de la ignorancia que le envolverán, hasta que se separe del cuerpo, estando privado de él y siendo objeto de la ira de [Dios]. Y ésto tiene grados que la reflexión no puede alcanzar. Por lo cual Dios ha completado el conocimiento por medio de la ley [religiosa]. En cambio, aquel a quien Dios da este Intelecto, cuando se separa del cuerpo, continúa siendo una cierta luz que alaba a Dios y le glorifica, en compañía de los profetas, de los justos, de los mártires y de los santos. jQué hermosa compañía! ${ }^{64}$.

Y por si quedasen dudas sobre la naturaleza de los dones divinos, aclara lo siguiente en El régimen del soítario, obra también de madurez, compuesta seguramente al final de su vida:

son dones divinos con los que Dios Altísimo distingue a las creaturas que El quiere, sin que el hombre tenga en ello participación alguna

y sigue unas líneas más adelante:

por dones divinos se entienden aquéllos de los que no es posible que el hombre sea su causa ${ }^{65}$.

61 Este hadịt es apócrifo y tiene origen platónico y neoplatónico. Véase: Goldziher, I., Neuplatonische und Gnostische elemtnte in Hadit en «Zeitschrift für Assyriologie», XXII, 1908, p. 317 y ss. Sgún Altmann (Ibn Bājja on Man's Ultimate Felicity», en Harry Austyn Wolfson Jubilee Volume on the occasion of his seventy-fifth birthday, vol. I. American Academy for Jewish Research, Saul Lieberman, Jerusalen, 1965., p. 98), y en ello sigo la interpretación de esta inclusión del hadit, aquí Avempace se refiere a la salida y vuelta sobre sí mismo del Intelecto, como ser que se piensa a sí mismo, tal como he expuesto más arriba y se veía concretamente en el texto citada más arriba del Tratado de la unión (op. cit. p. 383).

62 Alude, sin duda a lo que dice Aristóteles en la Etica a Nicómaco, 1. 10, 1172 a 6 y 1178 a 6.

63 Avempace, Carta del adiós, op. cit. p. 84.

64 Avempace, Tratado de la unión, p. 380.

65 Avempace, El régimen del solitario, op. cit., p. 161. 
Como conclusión se podría decir lo siguiente: la unión mística, para Avempace, ni es un don puramente gratuito de Dios, como podría ser el caso de los sufíes e incluso del propio Avicena, ni tampoco un logro del mero esfuerzo intelectual y abstractivo del hombre, sino un regalo y don divinos que concede Dios al ser humano, cuando éste ha culminado su ascenso de desprendimiento de la materia camino de una máxima espiritualidad, por la vía de la ciencia abstractiva. Este es el camino necesario que tiene en sus manos el hombre para acceder al Intelecto Agente, cuya unión es ciertamente un don y regalo divinos.

En ello se diferencia de otras actitudes místicas, concretamente la sufí. Para ésta, el camino de espiritualización se lograba mediante la vida ascética y moral por la cual el hombre se desprendía progresivamente de la materia. En el caso de Avempace, la moral, tiene un valor importante pero relativo a la vez, porque, en primer lugar, las virtudes muchas veces son comunes a hombres y animales:

como es la vergüenza en el león, la vanidad en el pavo real, el hacer caricias en el perro, la nobleza en el gallo, la astucia en el zorro ${ }^{66}$.

La única diferencia de que en el caso humano se llevan a cabo por voluntad y con libertad y no por naturaleza ${ }^{67}$ ya que en eso se caracterizan los auténticos actos humanos:

Acto humano es aquél que va precedido de un algo a lo cual obliga la reflexión en el agente, tanto si le precede o le sigue a la reflexión una pasión anímica [...]. El motor del hombre es algo que viene impuesto por la reflexión, en cuanto que es la reflexión, o cosa similar a esta, la que le obliga [a obrar], y ello, ya se trate de un pensamiento cierto ya de una opinión, el motor del animal, en cambio, es una afección pasiva que se da en el alma bestial. Así pues, el motor humano es una idea o una convicción que se encuentra en el alma ${ }^{68}$.

En segundo lugar las virtudes y la vida moral tienen una función eminentemente social encaminadas a hacer agradable y llevable la vida entre los seres humanos y solo serán auténticamente valiosas en un orden superior si con ellas se busca la propia perfección y espiritualidad verdadera. Y, por fin, en tercer lugar, aun en este último caso, las virtudes y la vida moral en general, no son sino un simple medio para un fin especulativo e intelectual más alto, logrado el cual los fines dejan de valer por sí mismos:

Los fines, no pueden ser perfectos si no se dan los medios. [...]. Los medios, cuando no se sigue de ellos el fin esencial, resultan ser de modo necesario y verdadero inútiles y vanos, en cambio, el fin esencial, no puede alcanzarse en modo ni manera alguna, si no se logran antes los medios. Una vez que se ha alcanzado [el fin], los medios son superfluos, innecesarios, y suponen un esfuerzo inútil, puesto que sin ellos se puede lograr [el fin $]^{69}$.

De este modo, al auténtico camino para lograr la unión con el Intelecto Agente, según Avempace, y que está en manos del hombre el recorrerlo es la vida de la ciencia racional, la abstracción desmaterializadora de las ciencias que culminan en el don gratuito de Dios de la unión con el Intelecto, tan próximo a El.

66 Avempace, El régimen del solitario, op. cit., p. 171.

67 Avempace, El régimen del solitario, op. cit., p. 45-47.

68 Avempace, El régimen del solitario, op. cit., pp. 120.

69 Avempace, Carta del adiós, op. cit. p. 75. 
Quedan, sin duda, muchos matices por perfilar en la delimitación de la razón, del intelecto humano (material, en acto y en hábito) y del Intelecto Agente. Pero basten estas breves indicaciones como esbozo para futuras investigaciones sobre el tema.

Joaquín Lomba

Departamento de Filosofía

Universidad de Zaragoza

Pedro Cerbuna, 12

50009 Zaragoza

jlomba@posta.unizar.es 